\title{
PENGEMBANGAN LKS TABELA BERBASIS BAHAN PRAKTIKUM LOKAL UNTUK MENINGKATKAN KETERAMPILAN PROSES SAINS SISWA SD
}

\author{
Development of Tabela Worksheets Based on Local Practicum Materials to Improve \\ Science Process Skills of Elementary Students
}

\section{Rita Rahmaniati" \\ Misyanto}

Agung Riadin

Universitas Muhammadiyah Palangkaraya, Palangka Raya,

Central Kalimantan, Indonesia

*email:

rahmaniatirita@yahoo.co.id

Kata Kunci:

LKS Tabela

Keterampilan Proses Sains

Hasil Belajar

\section{Keywords:}

Tabela Worksheets

Science Process Skill

Learning Outcomes

\begin{abstract}
Abstrak
Penelitian ini bertujuan untuk menghasilkan LKS Tabela berbasis bahan praktikum lokal yang standar, mengetahui peningkatan dan pengaruh keterampilan proses sains siswa, serta mendeskripsikan respon siswa setelah pembelajaran dengan menggunakan LKS Tabela. Metode yang digunakan dalam penelitian adalah metode penelitian pendidikan dan pengembangan dengan model ADDIE. Tahap pertama akan dilakukan analisis kebutuhan akan LKS Tabela berbasis bahan praktikum lokal. Tahap kedua dilakukan pengembangan model LKS Tabela berbasis bahan praktikum lokal menggunakan Model ADDIE. Tahap ketiga dilakukan Implementasi/pengujian tingkat keefektifan, efisiensi, serta kemenarikan produk hasil pengembangan menggunakan rancangan kuasi eksperimen dengan desain (prestest-postest control group). Hasil uji coba prosuk dan uji coba peggunaan menunjukkan bahwa LKS Tabela memiliki kriteria kemenarikan baik dengan skor 3,3I, kemudahan baik dengan skor 3,33, kriteria kebermanfaatan sangat baik dengan kategori skor 3,60. Hasil pengembangan LKS Tabela melalui proses hasil uji ahli dinyatakan layak digunakan sebagai bahan ajar/media pembelajaran ditunjukkan pada uji signifikansi yakni adanya pengaruh LKS Tabela terhadap hasil belajar nilai $t$ hitung $>t$ tabel $(7,442>1,668)$. Pada uji kefektifan menunjukkan tidak ada perbedaan secara signifikan yang ditunjukkan nilai $t$ hitung $>$ t tabel $(1,615<1,673)$, namun jika dilihat dari hasil belajar siswa menunjukkan peningkatan yaitu diperoleh rata rata pre-test yaitu 43,44 dan post-test 6I,09. Perbedaan skor rata rata antara pre-test dan post-test yaitu 17,65 dan N-gain sebesar 0,31 dengan kategori sedang. Respon siswa positif terhadap pembelajaran dengan menggunakan LKS Tabela.
\end{abstract}

\begin{abstract}
This study aims to produce a Tabela LKS based on standard local practicum material, to know the increase and influence of students 'science process skills, and to describe students' responses after learning by using Tabela LKS. The method used in the research is the method of education research and development with the ADDIE model. The first stage will be a needs analysis of the Tabela LKS based on local lab materials. The second stage was the development of the Tabela LKS model based on local lab materials using the ADDIE Model. The third stage is carried out Implementation / testing the level of effectiveness, efficiency, and product attractiveness of the results of development using a quasiexperimental design with a design (prestest-posttest control group). The results of the trial process and the use of the test show that the Tabela LKS has good attractiveness criteria with a score of 3.3I, good convenience with a score of 3.33, the usefulness criteria are very good with a score category of 3.60. The results of the development of Tabela worksheets through the process of expert test results are declared feasible to use as instructional materials / learning media shown in the significance test namely the effect of Tabela LKS on learning outcomes $t$ count values $>t$ table $(7.442>1.668)$. In the effectiveness test showed no significant difference indicated by the value of $t$ count $>t$ table $(1.615<1.673)$, but when viewed from student learning outcomes showed an increase that is obtained by the average pretest that is 43.44 and posttest 61.09 . The difference in the average score between pretest and posttest is I 7.65 and $N$-gain is 0.31 with the medium category. Positive student responses to learning by using Tabela LKS.
\end{abstract}

Accepted

October 2018

Published

December 2018 siswa untuk memiliki keterampilan proses sains. Rendahnya proses sains siswa dapat mempengaruhi kemampuan siswa untuk berfikir secara kritis, kreatif dan inovatif, siswa mudah terpengaruh oleh pendapat
Selama ini LKS yang di gunakan guru dikelas juga tidak

terdapat langkah-langkah metode ilmiah yang menuntun

\section{PENDAHULUAN}

,


orang lain, menghindari masalah, memecahkan masalah tanpa berfikir yang mendalam, belum dapat memecahkan masalah sendiri, dan merasa rendah diri apabila harus berbeda dengan orang lain. Jika kondisi tersebut dibiarkan berlarut larut dan tidak segera diperbaiki, maka akan berdampak pula pada hasil belajar siswa secara keseluruhan. Oleh karena itu perlunya pengembangan perangkat pembelajaran khususnya Lembar Kerja Siswa (LKS) (Desianti et al., 20I5).

LKS yang sesuai dengan tuntutan kurikulum IPA yaitu LKS yang mengacu pada pendekatan keterampilan proses melalui eksperimen dalam LKS mampu menumbuhkan kemampuan berpikir, bekerja dan bersikap ilmiah serta mengomunikasikannya sebagai aspek penting kecakapan hidup, sehingga lebih menekankan pada pemberian pengalaman belajar secara langsung. Pengembangan LKS Tabela berbasis bahan lokal akan menghasilkan LKS yang diharapkan dapat meningkatkan keterampilan proses sains siswa, sehingga pembelajaran lebih bermakna (Anggraini et al., 20I6).

Pengembangan LKS Tabela Berbasis Bahan Praktikum Lokal Untuk Mengembangkan Keterampilan Proses Sains Siswa SD Negeri, agar mampu mengahadapi segala tantangan dan permasalahan yang terjadi dalam kehidupan nyata. Tabela merupakan akronim dari bahasa Dayak yang berarti muda. LKS Tabela Berbasis Bahan Praktikum Lokal dimaksudkan disini adalah seperangkat LKS yang di desain sesuai dengan karakteristik siswa SD yang masih muda dan memiliki imajinasi tinggi dengan berbagai potensi yang berbeda yang mencoba mengaitkan bahan/sumber belajarnya dengan bahan praktikum lokal khususnya di Kalimantan Tengah (Ardhiantari et al., 20I5).

LKS merupakan lembaran di mana siswa mengerjakan sesuatu terkait dengan apa yang sedang dipelajarinya. Sesuatu yang dipelajari sangat beragam, seperti eksperimen, mengidentifikasi, membuat tabel, melakukan pengamatan, menggunakan mikroskop atau alat pengamatan lainnya dan menuliskan atau menggambar hasil pengamatannya, melakukan pengukuran dan mencatat data hasil pengukurannya, menganalisis data hasil pengukuran, dan menarik kesimpulan. Untuk mempermudah siswa melakukan proses-proses belajar, digunakanlah LKS (Suriyana et al., 2015).

Keterampilan proses sains adalah semua keterampilan yang diperlukan untuk memperoleh, mengembangkan, dan menerapkan konsep-konsep, hukum-hukum, dan teori-teori IPA, baik berupa keterampilan mental, keterampilan fisik maupun keterampilan sosial. Keterampilan proses sains terdiri atas keterampilanketerampilan dasar (basic skills) dan keterampilanketerampilan terintegrasi (integrated skills). Keterampilan-keterampilan dasar meliputi enam keterampilan, yakni mengobservasi, mengklasifikasi, memprediksi, mengukur, menyimpulkan dan mengkomunikasikan. Sedangkan keterampilanketerampilan terintegrasi terdiri atas mengidentifikasi variabel, membuat tabulasi data, menyajikan data dalam bentuk grafik, menggambarkan hubungan antar variabel, mengumpulkan dan mengolah data, menganalisis penelitian, menyusun hipotesis, mendefinisikan variabel secara operasional, merancang penelitian dan melaksanakan eksperimen (Lepiyanto, 20I4).

Keterampilan proses sains sebagai pendekatan dalam pembelajaran sangat penting karena menumbuhkan pengalaman selain proses belajar. Mengingat semakin banyaknya sekolah yang telah memiliki laboratorium biologi, sehingga perlu upaya meningkatkan efektivitas pembelajaran, khususnya prestasi hasil belajar kognitif yang didukung oleh keterampilan serta sikap dan prilaku yang baik. Oleh karena itu para guru hendaknya secara bertahap mulai bergerak melakukan penilaian hasil belajar dalam aspek keterampilan dan sikap (Acesta, 2014). 
Ada beberapa hal yang mempengaruhi keterampilan proses sains yang dituntut untuk dimiliki siswa. Faktor yang berpengaruh terhadap keterampilan proses sains, di antaranya yaitu perbedaan kemampuan siswa secara genetik, kualitas guru serta perbedaan strategi guru dalam mengajar (Amnie et al., 20I4). Indikator keterampilan proses sains dijabarkan pada Tabel I.

Tabel I. Indikator keterampilan proses sains

\begin{tabular}{|c|c|}
\hline $\begin{array}{c}\text { Keterampilan } \\
\text { Proses Sains }\end{array}$ & Indikator \\
\hline $\begin{array}{l}\text { Mengamati } \\
\text { (observasi) }\end{array}$ & $\begin{array}{l}\text { I. Menggunakan sebanyak mungkin indera } \\
\text { 2. Mengumpulkan atau menggunakan } \\
\text { fakta yang relevan }\end{array}$ \\
\hline $\begin{array}{l}\text { Mengelompokkan } \\
\text { (klasifikasi) }\end{array}$ & $\begin{array}{l}\text { 3. Mencatat setiap pengamatan secara } \\
\text { terpisah } \\
\text { 4. Mencari perbedaan dan persamaan } \\
\text { 5. Mengkontraskan ciri-ciri } \\
\text { 6. Membandingkan } \\
\text { 7. Mencari dasar pengelompokkan atau } \\
\text { 8. Menggolongan } \\
\text { 8. Mabungkan hasil-hasil pengamatan }\end{array}$ \\
\hline $\begin{array}{l}\text { Menafsirkan } \\
\text { (interpretasi) }\end{array}$ & $\begin{array}{l}\text { 9. Menghubungkan hasil-hasil pengamatan } \\
\text { I0. Menemukan pola dalam suatu seri } \\
\text { pengamatan } \\
\text { II. Menyimpulkan }\end{array}$ \\
\hline $\begin{array}{l}\text { Meramalkan } \\
\text { (prediksi) }\end{array}$ & $\begin{array}{l}\text { 12. Menggunakan pola-pola hasil } \\
\text { pengamatan } \\
\text { I3. Mengemukakan apa yang mungkin } \\
\text { terjadi pada keadaan yang belum } \\
\text { diamati }\end{array}$ \\
\hline $\begin{array}{l}\text { Mengajukan } \\
\text { pertanyaan }\end{array}$ & $\begin{array}{l}\text { I4. Bertanya apa, bagaimana, dan mengapa } \\
\text { I5. Bertanya untuk meminta penjelasan } \\
\text { 16. Mengajukan pertanyaan yang berlatar } \\
\text { belakang hipotesis }\end{array}$ \\
\hline Berhipotesis & $\begin{array}{l}\text { 17. Mengetahui bahwa ada lebih dari satu } \\
\text { kemungkinan penjelasan dari satu } \\
\text { kejadian } \\
\text { 18. Menyadari bahwa suatu penjelasan } \\
\text { perlu diuji kebenarannya dalam } \\
\text { memperoleh bukti lebih banyak }\end{array}$ \\
\hline $\begin{array}{l}\text { Merencanakan } \\
\text { eksperimen }\end{array}$ & $\begin{array}{l}\text { 19. Menentukan alat/bahan/sumber yang } \\
\text { akan digunakan } \\
\text { 20. Menentukan variabel atau faktor } \\
\text { penentu. } \\
\text { 21. Menentukan apa yang akan diukur, } \\
\text { diamati, dicatat } \\
\text { 22. Menentukan apa yang akan } \\
\text { dilaksanakan berupa langkah kerja }\end{array}$ \\
\hline $\begin{array}{c}\text { Menggunakan } \\
\text { alat/bahan }\end{array}$ & $\begin{array}{l}\text { 23. Memakai alat dan bahan } \\
\text { 24. Mengetahui alasan mengapa } \\
\text { menggunakan alat/bahan } \\
\text { 25. Mengetahui bagaimana menggunakan } \\
\text { alat dan bahan }\end{array}$ \\
\hline $\begin{array}{c}\text { Menerapkan } \\
\text { konsep }\end{array}$ & $\begin{array}{l}\text { 26. Menggunakan konsep yang telah } \\
\text { dipelajari dalam situasi baru } \\
\text { 27. Menggunakan konsep pada pengalaman } \\
\text { baru untuk menjelaskan apa yang } \\
\text { sedang terjadi }\end{array}$ \\
\hline Berkomunikasi & $\begin{array}{l}\text { 28. Menggambarkan data empiris hasil } \\
\text { eksperimen atau pengamatan dengan } \\
\text { grafik, tabel, dan diagram } \\
\text { 29. Menyusun dan menyampaikan laporan } \\
\text { secara sistematis } \\
\text { 30. Menjelaskan hasil eksperimen atau } \\
\text { penelitian } \\
\text { 31. Membaca grafik atau tabel diagram }\end{array}$ \\
\hline
\end{tabular}

\author{
32. Mendiskusikan hasil kegiatan suatu \\ masalah atau suatu peristiwa \\ 33. Mengubah bentuk penyajian
}

\section{METODOLOGI}

Tahapan-tahapan dalam penelitian ini meliputianalisis kebutuhan, pengembangan model LKS Tabela Berbasis Bahan Praktikum Lokal, dan implementasi LKS Tabela Berbasis Bahan Praktikum Lokal untuk menguji keefektifan efisiensi dan kemenarikan produk hasil pengembangan. Lokasi Penelitian di SDN kota palangkaraya. Model pengembangan yang digunakan peneliti adalah model ADDIE terdiri dari 5 fase atau tahap utama yaitu Analisis, Design, Development, Implementation, dan Evaluation. Rancangan kegiatan penelitian ini terdiri dari tiga tahapan sebagai berikut:

Tahap I

Rancangan penelitian pada tahap pertama berupa survey, bertujuan untuk memperoleh data kebutuhan (need assessment). Melalui survey ini diharapkan akan diperoleh karakteristik model LKS Tabela Berbasis Bahan Praktikum Lokal. Hal ini berarti rancangan survey ini bertujuan untuk memperoleh dua macam data, yakni data tentang kebutuhan dan karakteristik model LKS Tabela Berbasis Bahan Praktikum Lokal pada siswa SD Kota Palangkaraya.

Subyek penelitian untuk memperoleh data akan kebutuhan dan karakteristik LKS Tabela Berbasis Bahan Praktikum Lokal adalah siswa dan guru bidang studi IPA pada SDN Kota Palangkaraya. Lokasi penelitian di SDN Kota Palangkaraya. Variabel penelitian yang menjadi fokus perhatian dalam penelitian ini adalah kebutuhan SDN Kota Palangkaraya mengenai LKS standar yang sesuai dengan kebutuhan. Untuk menggali data yang dimaksud digunakan instrumen penelitian oleh tim peneliti. Instrument terdiri dari angket dan lembar observasi. Data yang didapatkan dari angket analisis kebutuhan dan angket perangkat pembelajaran akan dianalisis dengan teknik analisis triangulasi. 
Tahap II

Rancangan tahap 2 ini berupa pengembangan produk dengan tujuan untuk menghasilkan produk LKS Tabela Berbasis Bahan Praktikum Lokal. Model pengembangan yang dipakai dalam penelitian ini adalah ADDIE. Langkah-langkah pengembangan model ADDIE adalah sebagai berikut:

I. Analisis.

Tahap awal dalam pengembangan ini adalah tahapan analisis, yaitu analisis terhadap 2 aspek yaitu silabus dan karakteristik siswa. Analisis kebutuhan LKS Tabela Berbasis Bahan Praktikum Lokal seperti yang akan dilakukan pada tahap I.

2. Desain.

Tahap kedua merancang/membuat kerangka LKS Tabela Berbasis Bahan Praktikum Lokal berdasarkan hasil analisis kebutuhan pada analisis tahap II. Bentuk rancangan LKS yang akan dikembangkan didalammnya mencakup langkah langkah kegiatan saintifik yang meliputi Identifikasi dan perumusan masalah, menyusun hipotesis/prediksi, merencanakan kegiatan penyelidikan/percobaan, mengumpulkan data, menganalisis data, mengkomunikasikan, dan menyimpulkan.

3. Development

Tahap ketiga ini mengembangkan LKS Tabela Berbasis Bahan Praktikum Lokal yang sesuai kebutuhan, yaitu LKS yang didalamnya memiliki sistematika sebagai berikut: judul, kompetensi yang akan dicapai, waktu penyelesaian, peralatan/bahan yang diperlukan untuk menyelesaikan tugas, informasi singkat, langkah kerja, tugas yang harus dilakukan, dan laporan yang harus dikerjakan, serta adanya lembar penilaian.

4. Implementasi

Tahap keempat ini dilakukan tahapan implementasi pengembangan LKS Tabela Berbasis Bahan Praktikum Lokal dilaksanakan dengan melibatkan satu kelas uji coba kelompok kecil. Metode pelaksanaan pada implementasi ini digunakan praeksperimen dengan desain (prestest-postest noncontrol group desain). Hasil uji coba kelompok kecil sebagai bahan melakukan revisi pengembangan LKS Tabela (kelayakan I). Selanjutnya di lakukan uji coba pada kelas Implementasi I (uji kelayakan II) melibatkan I kelas. Pada tahapan ini di maksudkan untuk melihat kelayakan produk LKS yang dikembangkan.

5. Evaluasi

Pada tahap ini akan dilakukan evaluasi terhadap produk LKS Tabela Berbasis Bahan Praktikum Lokal hasil pengembangan yang telah direvisi pada SD yang berbeda di Kota Palangkaraya menggunakan metode quasi eksperimen dengan desain (prestest-postest control group). Tujuan dilaksanakan evaluasi ini untuk menguji kefektifan produk LKS Tabela Berbasis Bahan Praktikum Lokal hasil pengembangan, terutama terhadap Keterampilan proses sains dan hasil belajar siswa. Adapun Teknik Pengumpulan Data dalam penelitian ini meliputi data hasil analisis kebutuhan dan valiasi ahli pengembangan LKS Tabela Berbasis Bahan Praktikum Lokal, data peningkatan keterampilan proses sains siswa, data hasil belajar, dan angket respon siswa terhadap produk hasil pengembangan.

Tahap III

Teknik analisis data dalam penelitian ini dengan menganalisa data tentang hasil wawancara, angket analisis kebutuhan, angket respon siswa, dan hasil validasi ahli dianalisis secara dekriptif presentase, data peningkatan dan pengaruh keterampilan proses sains dianalisis dengan menggunakan rumus $\mathrm{N}$-Gain dan uji $\mathrm{t}$.

\section{HASIL DAN PEMBAHASAN}

Pengembangan LKS Tabela setelah melalui tahapan tahapan dan validasi ahli serta uji coba produk, maka dihasilkan LKS yang efektif dan praktis. Isi LKS di sesuaikan dengan kebutuhan dan karakteristik siswa SD 
di kota Palangkaraya yang yang melatih siswa untuk terampil melakukan keterampilan proses sains. Bahan Praktikum lokal yang digunakan adalah bahan praktikum yang mudah di dapat di kalimantan tengah khusunya di kota palangkaraya dengan menggunakan contoh yang kontekstual, misalnya tanaman kalakai, kantong semar, tanaman buah masisin, dan elodia. Hasil validasi oleh ahli secara umum memberikan penilaian dari kategori cukup hingga sangat baik hingga di peroleh rata-rata baik $(3,9)$. Hasil uji coba produk dan uji coba penggunaan menunjukkan LKS Tabela memiliki kriteria kemenarikan baik dengan skor 3,31, kemudahan baik dengan skor 3,33, kriteria kebermanfaatan sangat baik dengan kategori skor 3,60.

Hasil tes keterampilan proses siswa menunjukkan bahwa terjadi peningkatan hasil belajar keterampilan dengan N-Gain berkategori sedang (kelas implementasi I) dan kategori tinggi (kelas implementasi 2). Pada uji kelayakan (kelas implementasi I) Secara statistik juga menunjukkan bahwa hasil tes keterampilan proses sains berbeda secara signifikan yang ditunjukkan nilai t hitung $>$ t tabel $(11,95>1,673)$. Pada uji kefektifan (kelas implementasi 2) secara statistik juga menunjukkan hasil tes keterampilan proses sains berbeda secara signifikan yang ditunjukkan nilai t hitung $>\mathrm{t}$ tabel $(15,476>\mathrm{I}, 734)$. Adanya pengaruh dan peningkatan hasil tes keterampilan proses ini menunjukkan bahwa pengembangan LKS berbasis keterampilan proses sains layak digunakan dalam pembelajaran IPA pada tema Fotosintesis dan efektif dalam meningkatkan kerja ilmiah siswa (Putri \& Widiyatmoko, 20I3). Penelitian Susilo \& Atun (20I7) menunjukkan bahwa LKS IPA dengan pendekatan guided inquiry mampu meningkatkan ketrampilan proses sains, kemampuan berpikir kritis, dan hasil belajar kognitis siswa SMP kelas VII.

Menurut siswa, pembelajaran dengan menggunakan LKS Tabela mereka lebih cepat memahami materi kuliah dan penerapannya dalam kehidupan sehari- hari. Interaksi antar siswa maupun dosen dan siswa tercipta baik dengan adanya diskusi. Berdasarkan hasil angket respon siswa dapat di lihat dari Gambar I berikut:

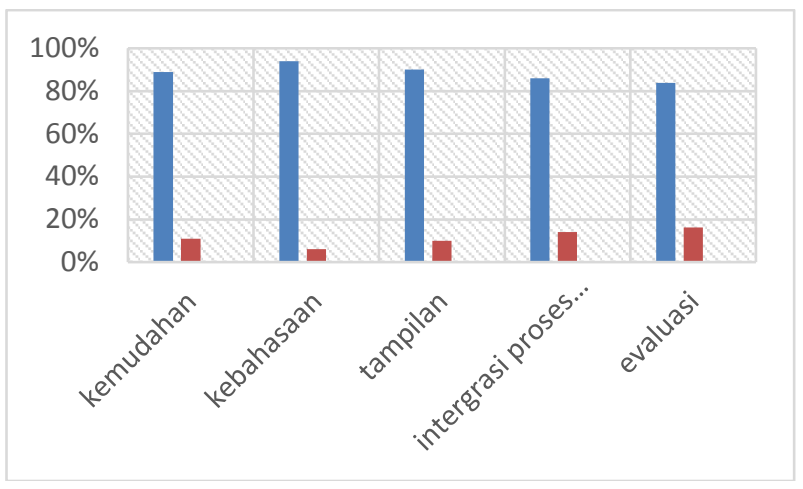

Gambar I. Diagram respon siswa

Sebagian besar siswa juga menyatakan bahwa tampilan LKS Tabela menarik, hal ini memberikan makna bahwa siswa merasa senang dengan pembelajaran. Soal yang tersedia di LKS membuat siswa belajar lebih percaya diri dan lebih bermakna serta mampu merefleksikan hasil belajarnya. Inilah yang membuat mereka lebih bersemangat dalam mengikuti pembelajaran, siswa merasa bahwa LKS Tabela bermanfaat bagi mereka, karena dalam pembelajaran menggunakan LKS Tabela siswa tidak hanya di nilai secara kognitif tetapi juga secara proses (Aristiani, 2016). Secara keseluruhan hasil angket ini menunjukkan bahwa LKS Tabela memberikan respon positif terhadap hasil belajar kognitif dan keterampilan proses siswa. Melalui pembelajaran yang positif ini diharapkan siswa mampu menggali pengetahuan lebih dari sekadar apa yang telah mereka peroleh dari materi pelajaran.

\section{KESIMPULAN}

Berdasarkan penelitian ini dihasilkan prototipe LKS Tabela berbasis bahan praktikum lokal hasil pengembangan yang mengacu pada langkah langkah proses sains yang layak dan efektif. Keterampilan proses sains siswa pada kelas implementasi I meningkat, yaitu skor pre-test 51,49 meningkat menjadi 82,92 dan $\mathrm{N}-$ Gain 0,35 dengan kategori sedang. dan secara statistik menunjukkankan adanya perbedaan signifikan 
nilai t hitung $>$ t tabel $(\mathrm{I} I, 95 \mathrm{I}>\mathrm{I}, 74)$. Pada uji kefektifan (kelas implementasi 2) menunjukkan bahwa terjadi peningkatan hasil belajar keterampilan dengan N-Gain berkategori tinggi sebesar 0,75 secara statistik juga menunjukkan hasil tes keterampilan proses sains berbeda secara signifikan yang ditunjukkan nilai t hitung $>\mathrm{t}$ tabel $(15,476>1,734)$. Selanjutnya model LKS Tabela berbasis bahan praktikum lokal salah satu alternatif yang dapat di gunakan guru untuk melatihkan keterampilan proses sains siswa SD, keterampilan Proses sains dapat di integrasikan dengan nilai-nilai karakter yang hendak guru tanamkan melalui keiatan Ilmiah, dan pengembangan produk lebih lanjut dapat dilakukan dengan pemanfaatan potensi kearifan lokal, sebab potensi kearifan lokal di Kalimantan Tengah masih banyak untuk dapat dijadikan bahan praktikum dan pembelajaran lainnya.

\section{REFERENSI}

Acesta, A. 2014. Penerapan Pendekatan Keterampilan Proses Sains untuk Meningkatkan Hasil Belajar Siswa dalam Pembelajaran IPA. Jurnal IImiah Pendidikan Dasar. I(2):96-106.

Amnie, E., Abdurrahman, \& Ertikanto, C. 2014. Pengaruh Keterampilan Proses Sains terhadap Penguasaan Konsep Siswa pada Ranah Kognitif. Jurnal Pembelajaran Fisika. 2(7):123137.

Anggraini, R., Wahyuni, S., Lesmono, A.D. 2016. Pengembangan Lembar Kerja Siswa (LKS) Berbasis Keterampilan Proses di SMAN 4 Jember. Jurnal Pendidikan Fisika. 4(4):350-356.

Ardhiantari, W., Fadiawati, N., \& Kadaritna, N. 2015. Pengembangan LKS Berbasis Keterampilan Proses Sains pada Materi Hukum-Hukum Dasar Kimia. Jurnal Pendidikan dan Pembelajaran Kimia. 4(I):3 12-323.

Aristiani, R. 2016. Meningkatkan Percaya Diri Siswa melalui Layanan Informasi Berbantuan Audiovisual. Jurnal Konseling GUSJIGANG. 2(2): $182-289$.

Desianti, N.W.H., Adnyana, P.B., \& Setiawan, I.G.A.N. 2015. Pengembangan Perangkat Pembelajaran IPA dengan Setting Sains Teknologi
Masyarakat untuk Meningkatkan Keterampilan Proses Sains dan Keterampilan Berpikir Kreatif Siswa SMP. Jurnal Pendidikan dan Pembelajaran IPA Indonesia. 5(I): I-I 2.

Lepiyanto, A. 2014. Analisis Keterampilan Proses Sains pada Pembelajaran Berbasis Praktikum. Bioedukasi: Jurnal Pendidikan Biologi. 5(4):I56I6I.

Putri, B.K. \& Widiyatmoko, A. 2013. Pengembangan LKS IPA Terpadu berbasis Inkuiri Tema Darah di SMP N 2 Tengaran. Jurnal Pendidikan IPA Indonesia. 2(2): I02-106.

Suriyana, Rifat, \& Zubaidah. 2015. Pengembangan Lembar Kerja Siswa Berbasis Masalah untuk Meningkatkan Hasil Belajar Di SMP. Jurnal Pendidikan dan Pembelajaran. 4(I):2 I600I.

Susilo, A. \& Atun, S. 2017. Pengembangan LKS IPA untuk Meningkatkan Ketrampilan Proses Sains Dan Kemampuan Berpikir Kritis Siswa SMP. Jurnal Edukasi Matematika dan Sains. 5(I):8-17. 